\title{
Evaluating the Corporate Social Responsibility and Organizational Performance based on Large-Scale Data Access and Management
}

\author{
Bin Chen ${ }^{1}$ and Ning Zhang ${ }^{2}$ \\ ${ }^{1}$ School of Business, Nantong University, Nantong 226019, China \\ ${ }^{2}$ School of Business, Renmin University of China, Beijing, 100872, China \\ E-mail: chenbin7776@163.com
}

\begin{abstract}
Information technology has entered a big-data era. Large-scale data is becoming the basic factors of production and it would affect the corporate social responsibility disclosure deeply, the use of big data has become the key factor to improve the competitiveness of enterprises. Through this empirical analysis, we can draw the following conclusions: corporate social responsibility is mainly composed of economic responsibility, legal responsibility, ethical responsibility and spontaneous responsibility. And CSR will have positive effect on organizational performance. All of these indicate that prompting enterprises staff to fulfill corporate social responsibility is helpful to improve the organizational performance.
\end{abstract}

Keywords: Corporate social responsibility; Information disclosure; Organizational performance; Big data

\section{Introduction}

In the economic globalization and management internationalization, with the progress of society competition, corporate social responsibility has attracted more and more attention of the whole society [1]. The corporate social responsibility is no longer being treated as a slogan, but as a strategic behavior and practice. To undertake and perform to stakeholders of corporate social responsibility, is expected to meet the needs of stakeholders of corporate social responsibility [2], has become the basis of legitimacy of the business enterprise. In the social background of China's economic transformation, change of the relationship between the employee and the organization is more complex, enterprise employee performance and corporate social responsibility has become the enterprises cannot withstand the pressure and motive force of development. At the macro level and enterprise financial performance of corporate social responsibility on the one hand, although there is a certain theoretical and practical significance [3], however, it is difficult to organize from the micro level to explain its mechanism of action and mechanism. The core content of big data as expected the next round of technological change, will in many aspects affect the corporate social responsibility information disclosure. In the big data environment, disclosure will also produce a new evolution of corporate social responsibility information at the same time [4], the social responsibility of the enterprise information in the production, transmission and storage and other aspects will show new characteristics.

For the huge amounts of data mining and a lot of people use, not only marked the growth of industrial productivity and consumers of a large number of surplus, but also specifically prompted the time has come for a big data. Therefore, big data is affecting every corner of the level of society and technology, has become a major problem that cannot be ignored. Big data lead the city changes reflected in many aspects. Need a lot of 
information mining natural geography and social and cultural city planning, including economic, population, public service, etc. all can improve meteorological decision support massive data management service level, not only pay attention to science, but also grasp the prospective[5-6]. Traffic management also needs a comprehensive collection of various traffic modes of data mining, real time finishing in time; improve the traffic congestion control, centralized control and timely response to emergencies, maintenance of city traffic all-weather operation. Big data also affects the Internet monitoring and security. One is the timely detection of radio network and intelligent network analysis of semantic search keywords public opinion, public opinion analysis, timely and comprehensive understanding of public issues, good at dealing with the emergency network, for network crime disposal in accordance with law. Two is the safety cannot do without collecting relevant data, data mining, first time prediction of natural disasters and social terror, early warning and emergency rescue capabilities have. With the development of society the government should have the courage to be in the hands of the data gradually opening up, supply more capable organizations or individuals to analyze and utilize, to speed up the benefit of mankind.

In deep mining and analyzing existing literature on the basis of combing review organization of social responsibility, organizational identity and organizational citizenship behavior theory, constructs the organization mechanism of the influence of the social responsibility on organizational citizenship behavior model. Then we make empirical analysis to test the effect of social responsibility on organizational performance by reliability analysis and multiple regression analysis.

\section{Literature Review}

\subsection{Corporate Social Responsibility}

The development of corporate social responsibility and related literature has undergone a long history. In 1953, Bowen first put forward the merchant's social responsibility theory in his book "Social Responsibilities of the Businessman", and puts forward a point of view that enterprise and society has a certain relationship [7]. Later, a lot of industrialism and writers have on this novel presents the relationship between business and society commented, Bowen in his book first admitted the enterprise should bear the social responsibility, in answer to the problem whether the enterprise should bear the responsibility, Bowen's answer is obviously. It also acknowledges that corporate social responsibility is not to solve all the problems of society as a "panacea", corporate social responsibility need encouragement and support. Secondly, he put forward the second question, what is the social responsibility? Bowen proposed the concept of corporate social responsibility, the social impact of a strong. During this period, the United States issued many relevant laws to control the behavior of enterprises, but also many scholars in United States rapidly transform the social environment rational thinking, and the introduction of the laws related too many on the protection of workers and consumers control the behavior of enterprises. A lot of consumer rights movement, the destruction of the relationship between the enterprise and the public, in this period, the enterprise senior advocates of corporate social responsibility, but in reality is to regard it as a public relations strategy. Corporate social responsibility get little support and implementation of all levels of the organization, most mid-level managers that corporate social responsibility to destroy the financial performance of the organization in the bottom line, so they were sloppy deal with corporate social responsibility. Friedman firmly opposed to corporate social responsibility [8], he believes that enterprises and there is only one kind of responsibility, that is, "in an open, free without the fraud of the competition and make full use of the resources and capabilities to create the maximum profit for shareholders. 


\subsection{Corporate Social Performance}

Corporate social performance studies are seen as a description, measure and forecast corporate behavior in the same field under the influence of other social factors. In the 80's, there are two big contribution to the research on corporate social responsibility: one is the corporate social performance model, and the responsibility is divided into four categories: economic responsibility, legal liability, ethics responsibility and discretion responsibility, solves the dispute about responsibility; The corporate social response strategies are divided into four reactive as adaptive, defensive, and active, social response, especially to the enterprise to supplement and complete, point of view. At the same time also raised the consumer, environmental, racial discrimination, product safety, occupational safety, stakeholder stakeholders responsible. Second, the stakeholder theory has been put forward, it can solve the problem of social fuzziness, from then on, corporate social responsibility on stakeholder level discussion, no longer under the social state .Carol requirements of corporate social performance: one is corporate social responsibility should be measured; second, enterprises are facing the social problems must be identified; the third idea response can choose according to the enterprise.

Wood (1991) developed the model, combined the model with related theories such as system theory [9], stakeholder management theory and other social problems. Develop three-dimensional model into other theoretical traditions, its purpose is forming a more practical and useful for the administration model. The positive effect of the corporate social performance and corporate financial performance has not been verified can be explained by the intermediary variables and environmental contingency, this view allows us to see the impact on corporate financial performance of the full potential of corporate social responsibility initiative. Many of these factors are associated with human resources management related to the intermediary variables related. Frolova (2014) pointed out that corporate social responsibility and human resource management cooperation aims to have an important impact on the outcome of the organizational performance [10].

\section{Questionnaire and Data Collection}

\subsection{Questionnaire Design}

Questionnaire is a technique of researchers to collect data, it can be said is the behavior and attitude of the individual of a measurement technique; its function mainly is to measure, especially on some main variables measure. The main function of the questionnaire is to measure the variables that need to study, so the questionnaire must be targeted for the variables. Questionnaire design to adhere to the principle of two aspects: get what you want to get information, too much or too little. Understand and analyze the use of your data, as close as possible to the research question and hypothesis. Before questionnaire design, we should decide some problems of the following five types: (1) determine the primary and secondary data collection methods, such as access, questionnaire, observation and reading literature; (2) decided to remove the methods of subjects, including support institutions, research purpose, data confidentiality and not to be named, etc; (3) decided to set up within the framework of the questionnaire problem of continuity, order and other skills; (4) decided to each variable, namely each sequence of consecutive questions; (5) decided to use a preprogrammed answers or free to answer the question.

Questionnaire mainly uses the usual form of, with rigorous theory and related academic research achievements, especially with regard to a constitutive read the concept, theory and empirical research of, with related observed variables or indicators to construct measure, mainly used for executives and human resource managers tube of executives and human resource management department senior management personnel questionnaires for data collection. Study involving all the variables using Likert scale, respectively to 
corporate social responsibility with four observed variables as economic responsibility, legal responsibility, ethical responsibility and spontaneous responsibility to carry the scoring; organizational performance is respectively the two observed variables as operational performance and financial provided performance. Organizational performance mainly by subjective performance evaluation method, the objective performance appraisal method is not used, mainly because of the need for objective evaluation method of data relates to the subjects of confidential commercial enterprises, many companies reluctant to expose the true, such as the rate of return on assets and many objective financial measure index, so we adopt is subjective evaluation indicators such as market share ratio, profitability and market growth rate, and other indicators.

\subsection{Sample and Statistical Analysis}

Our choice is mainly depend on the investigation of the enterprise scale, mainly from employees to carry out the provisions; we must request the number of employees in more than 100 enterprises. We surveyed the requirements of enterprises must have a clear strategy for enterprise, including human resources management strategy and corporate social responsibility strategy. Our investigation of the enterprises have not set up the corporate social responsibility of the functional departments, corporate social responsibility departments mainly lies in the hands of the enterprise executive team and high-level decision-making team, but part of it relates to with employees about the corporate social responsibility management functions are almost always in the hands of the human resources management of departments in the, so we survey or questionnaire respondents were mainly is in charge of the enterprise human resources executives or enterprise human resources executives, industry related to the widely distributed in financial services, real estate, it, food and beverage, processing and manufacturing, mainly by online guide and questionnaire to fill a way to collect.

Before distribute questionnaire, we have chosen the nearly 10 companies to relevant personnel interviews and make questionnaire test, mainly to test our questionnaire design is consistent with the corporate social responsibility and organization performance management is consistent. In the pre investigation, we mainly test questions and relevant theoretical research kernel consistency and enterprise management practice, comparison and modification of the context words and ambiguous expression content of comprehensive improvement and revision the work, then we make coil design more scientific and more reliable data, in order to make the reliability and validity of the obtained consistency, and make more accurate measurement of relevant variables. The survey questionnaires were distributed to 350, which the network issuing the questionnaire 300 copies, by letter post 50 questionnaires, network publishing questionnaires recovered 270 questionnaires, recovery rate of $90 \%$, the letters mailed questionnaire recovery 30 copies, the recovery rate of $60 \%$, recovery of the entire 300 copies of effective questionnaires, questionnaire recovery rate is $86 \%$, and are all valid questionnaires. We make the statistical analysis of the industrial distribution, as shown in table 1.From table1, we can find that samples in wholesale and retail is 64 , account for $21.3 \%$ of the total, and the other industries samples are similar. Then we make the statistical analysis of the sample, as shown in Table 2.

Table 1. The Statistical Analysis of the Industrial Distribution

\begin{tabular}{|c|c|c|}
\hline Industry & number & Percent \\
\hline $\begin{array}{c}\text { The financial services } \\
\text { industry }\end{array}$ & 47 & $15.66 \%$ \\
\hline Telecommunication industry & 25 & $8.33 \%$ \\
\hline Education services & 46 & $15.32 \%$ \\
\hline Wholesale and retail & 64 & $21.33 \%$ \\
\hline
\end{tabular}




\begin{tabular}{|c|c|c|}
\hline $\begin{array}{c}\text { Dining entertainment } \\
\text { industry }\end{array}$ & 42 & $14.00 \%$ \\
\hline The construction industry & 18 & $6.00 \%$ \\
\hline $\begin{array}{c}\text { Processing and } \\
\text { manufacturing }\end{array}$ & 35 & $11.67 \%$ \\
\hline other & 23 & $7.66 \%$ \\
\hline Total & 300 & $100 \%$ \\
\hline
\end{tabular}

Table 2. The Statistical Analysis of the Sample

\begin{tabular}{|c|c|c|c|}
\hline Item & Content & number & Percent \\
\hline \multirow{2}{*}{ Gender } & Male & 174 & $58.0 \%$ \\
\cline { 2 - 4 } & Female & 126 & $42.0 \%$ \\
\hline \multirow{4}{*}{ Age } & Under 30 & 44 & $14.66 \%$ \\
\cline { 2 - 4 } & $31-40$ & 102 & $34.0 \%$ \\
\cline { 2 - 4 } & $40-50$ & 93 & $31.0 \%$ \\
\hline \multirow{3}{*}{$\begin{array}{c}\text { Education } \\
\text { background }\end{array}$} & More than 50 & 61 & $20.33 \%$ \\
\cline { 2 - 4 } & High school and college & 79 & $26.33 \%$ \\
\cline { 2 - 4 } & Undergraduate & 126 & $42.0 \%$ \\
\hline \multirow{3}{*}{\begin{tabular}{c} 
Position \\
\cline { 2 - 4 }
\end{tabular}} & Graduate & 95 & $31.66 \%$ \\
\cline { 2 - 4 } & employees & 201 & $67.0 \%$ \\
\hline \multirow{3}{*}{$\begin{array}{c}\text { Working } \\
\text { year }\end{array}$} & First-line managers & 76 & $25.33 \%$ \\
\cline { 2 - 4 } & Middle managers & 23 & $8.66 \%$ \\
\cline { 2 - 4 } & Less than 1year & 101 & $33.66 \%$ \\
\cline { 2 - 4 } & 1-5 year & 94 & $31.33 \%$ \\
\hline
\end{tabular}

\subsection{Variable Description}

The independent variables is corporate social responsibility, there are four primary indicators of corporate social responsibility as economic responsibility, legal responsibility, ethical responsibility and spontaneous responsibility. All indicators were shown in table 3.The intermediary variables is organizational identification, the dependent variable is organizational performance, and it includes two indicators as "financial performance and operating performance".

Table 3. Description of Primary Indicators

\begin{tabular}{|c|c|c|}
\hline Code & Variables & Variable description \\
\hline \multirow{3}{*}{$\begin{array}{c}\text { Economic } \\
\text { responsibility } \\
\alpha 1\end{array}$} & Fair development & $\begin{array}{c}\text { employees will share the achievements of } \\
\text { enterprise economic development }\end{array}$ \\
\cline { 2 - 3 } & Revenue sharing & $\begin{array}{c}\text { Implementation of revenue sharing plan } \\
\text { internally }\end{array}$ \\
\cline { 2 - 3 } & A2 & The implementation of equal pay system \\
\hline \multirow{2}{*}{$\begin{array}{c}\text { Legal } \\
\text { responsibility } \alpha 2\end{array}$} & Legal contract A4 & All employees signed a labor contract \\
\cline { 2 - 3 } & Security A5 & To ensure employee health and safety \\
\cline { 2 - 3 } & $\begin{array}{c}\text { Information } \\
\text { disclosure A6 }\end{array}$ & $\begin{array}{c}\text { Disclosure information of corporate social } \\
\text { responsibility }\end{array}$ \\
\hline Ethical & Personal care A7 & Ethical concern for employees \\
\hline
\end{tabular}




\begin{tabular}{|c|c|c|}
\hline \multirow[t]{2}{*}{ responsibility $\alpha 3$} & Atmosphere A8 & Workplace ethics atmosphere is better \\
\hline & Dignity A9 & $\begin{array}{l}\text { Let employees have decent or dignified } \\
\text { labor }\end{array}$ \\
\hline \multirow{3}{*}{$\begin{array}{c}\text { Spontaneous } \\
\text { responsibility } \\
\alpha 4\end{array}$} & $\begin{array}{l}\text { Vulnerable group } \\
\text { A10 }\end{array}$ & Protect the weak group of employees \\
\hline & Gender A11 & $\begin{array}{l}\text { Use a certain percentage of minority } \\
\text { employees and female employees }\end{array}$ \\
\hline & Aid program A12 & $\begin{array}{l}\text { Implement the employee assistance } \\
\text { program }\end{array}$ \\
\hline
\end{tabular}

\section{Empirical Analysis}

\subsection{The Reliability Analysis}

In this section, we make reliability analysis of organizational social responsibility based on organizational social responsibility and organizational performance. For the analysis of the reliability of the scale, this study excludes certain items after the general correlation coefficient (CITC), and the Cronbach's alpha coefficient of the evaluation and test. Cronbach's alpha coefficient ranged from 0 to 1 , the academic circles generally believe that 0.7 is the scale of the boundary value, a series of numerical above 0.7 is better, a numerical between $0.7-0.8$ is pretty good; a figure of between 0.9 very good. If below the 0.35 , then must be rejected. Through analysis of SPSS17.0 software, in the overall sample of the internal consistency analysis results are shown in the following table shows the Cronbach's alpha coefficient of 0.954 , indicating that the data obtained by the formal investigation has good reliability. And we make the reliability analysis of each factor, as shown in Table 3.

Table 4. The Reliability Analysis of each Factor

\begin{tabular}{|c|c|c|c|c|}
\hline Factor & $\begin{array}{l}\text { Evaluation } \\
\text { index }\end{array}$ & $\begin{array}{l}\text { corrected item- } \\
\text { total correlation }\end{array}$ & $\begin{array}{l}\text { Cronbach's } \\
\text { Alpha if item } \\
\text { deleted }\end{array}$ & $\begin{array}{l}\text { Cronbach 's } \\
\text { Alpha }\end{array}$ \\
\hline \multirow{3}{*}{$\begin{array}{l}\text { Economic } \\
\text { responsibility }\end{array}$} & A1 & 0.7951 & 0.8462 & \multirow{3}{*}{0.8213} \\
\hline & A2 & 0.8240 & 0.8758 & \\
\hline & A3 & 0.7249 & 0.7562 & \\
\hline \multirow{3}{*}{$\begin{array}{l}\text { Legal } \\
\text { responsibility }\end{array}$} & A4 & 0.8637 & 0.9014 & \multirow{3}{*}{0.8750} \\
\hline & A5 & 0.7325 & 0.7826 & \\
\hline & A6 & 0.6951 & 0.7439 & \\
\hline \multirow{3}{*}{$\begin{array}{l}\text { Ethical } \\
\text { responsibility }\end{array}$} & A7 & 0.7630 & 0.8261 & \multirow{3}{*}{0.8052} \\
\hline & A8 & 0.8237 & 0.8852 & \\
\hline & A9 & 0.7483 & 0.8029 & \\
\hline \multirow{3}{*}{$\begin{array}{l}\text { Spontaneous } \\
\text { responsibility }\end{array}$} & A10 & 0.7816 & 0.8254 & \multirow{3}{*}{0.7984} \\
\hline & A11 & 0.7947 & 0.8496 & \\
\hline & A12 & 0.7359 & 0.7741 & \\
\hline \multirow{5}{*}{$\begin{array}{l}\text { Organizational } \\
\text { identification }\end{array}$} & B1 & 0.7524 & 0.7961 & \multirow{5}{*}{0.7235} \\
\hline & B2 & 0.6985 & 0.7368 & \\
\hline & B3 & 0.6652 & 0.7014 & \\
\hline & B4 & 0.6352 & 0.6902 & \\
\hline & B5 & 0.6759 & 0.7267 & \\
\hline \multirow{2}{*}{$\begin{array}{l}\text { Organizational } \\
\text { performance }\end{array}$} & $\mathrm{C} 1$ & 0.7826 & 0.8525 & \multirow{2}{*}{0.7916} \\
\hline & $\mathrm{C} 2$ & 0.7951 & 0.8746 & \\
\hline
\end{tabular}




\subsection{Validity Analysis}

In this paper, we use exploratory factor analysis to test the structure validity of the scale. The formal factor analysis is needed to analyze the KMO and Bartley sphere test of the variables before the factor analysis. Generally, it is believed that $\mathrm{KMO}>0.9$, very suitable in 0.8-0.9, suitable in 0.7-0.8; and will be non-suitable in 0.6-0.7; Bartlett's test of sphericity value should be at a significance level of less than 0.05 , Bartlett test is less than 0.001 and factor correlation coefficient matrix of non unit matrix, to extract the minimal factor and can explain most of the variance.

Table 5. The Result of KMO Statistical Test

\begin{tabular}{|c|c|c|}
\hline \multicolumn{2}{|c|}{ Kaiser-Meyer-Olkin } & 0.683 \\
\hline \multirow{3}{*}{ Bartlett test } & Approximate chi-square & 132.554 \\
\cline { 2 - 3 } & $\mathrm{df}$ & 16 \\
\cline { 2 - 3 } & Sig. & 0.000 \\
\hline
\end{tabular}

\subsection{Confirmatory Factor Analysis}

Our research is mainly confirmatory factor analysis method, mainly because our study is established on basis of the existing theory and test results to construct the model, in the context of China collected data and validate has some theory is and the management practice of Chinese enterprises is inosculated, on the assumption that the obtained test research based on improvement and innovation of existing theories, in had assumed not to support the proposition, re of relevant theoretical reflection and to carry on the discussion, with a view to the future research about this new direction. The verification of factor analysis method the basic idea of our study is consistent with the. Therefore, we make empirical study of confirmatory factor analysis.

\section{Table 6. Second-Order Factor Loading of Corporate Social Responsibility}

\begin{tabular}{|c|c|c|c|c|}
\hline Dimensions & Factor & Stand. factor load & P value & Stand.error \\
\hline \multirow{3}{*}{$\begin{array}{c}\text { Corporate } \\
\text { social }\end{array}$} & Economic responsibility & 0.825 & 0.000 & 0.087 \\
\cline { 2 - 5 } responsibility & Legal responsibility & 0.716 & 0.000 & 0.110 \\
\cline { 2 - 5 } & Ethical responsibility & 0.935 & 0.000 & 0.081 \\
\cline { 2 - 5 } & Spontaneous responsibility & 1.046 & 0.000 & 0.107 \\
\hline
\end{tabular}

Then we make overall fitting degree of the measurement model, as shown in table 7.From table 7, it can be seen that the overall model of corporate social responsibility is better, and X2/df is between 2 and 5, and it meets the requirements.. The fitting index of the index of AGFI is only slightly smaller than that of the rest, and the other fitting indexes are above 0.90 , which is in line with the requirements.. Therefore, the two order model of CSR can be accepted, and the above parameters are effective.

Table 7. The Overall Fitting Degree of the Measurement Model

\begin{tabular}{|c|c|c|}
\hline Fitting index & value & Fitting state \\
\hline$\chi 2$ & 211.980 & \\
\hline $\mathrm{df}$ & 69 & \\
\hline$\chi^{2 / \mathrm{df}}$ & 3.117 & Very good \\
\hline GFI & 0.913 & good \\
\hline AGFI & 0.866 & good \\
\hline CFI & 0.933 & Very good \\
\hline IFI & 0.933 & \\
\hline
\end{tabular}




\begin{tabular}{|c|c|c|}
\hline NFI & 0.905 & good \\
\hline ECVI & 0.956 & Very good \\
\hline RMSEA & 0.084 & pass \\
\hline
\end{tabular}

\subsection{Regression Analysis}

We test the relationship between organizational social responsibility and organizational performance by regression analysis: first of all, we analyze organization social responsibility influence on financial performance; then analyze the corporate social responsibility for operational performance. First, we analyze the corporate social responsibility and financial performance, as shown in Table 8. And the equation of corporate social responsibility (CSR), organizational identification (OI) and financial performance (FP) can be shown as:

$$
\begin{aligned}
& F P=\alpha_{1} C S R+\mu_{1} \\
& F P=\alpha_{2} C S R+\beta_{2} O I+\mu_{2}
\end{aligned}
$$

From the table we can see, the regression results show that formula 1 in the constant coefficient for 1.5635 , significant test results is 0.002 ; organization social responsibility beta $=0.442$, significant test results for 0.014 . The results showed that the organizational social responsibility had a positive correlation to the financial performance of the enterprise. In formula 2, organization social responsibility significance test results of 0.021 , organizational identification of significant test results was 0.005 , and organizational identification has a certain intermediary effect.

Table 8. Regression Analysis of CSR and Financial Performance

\begin{tabular}{|l|l|l|l|l|l|l|}
\hline \multirow{2}{*}{ Model } & \multicolumn{2}{|l|}{$\begin{array}{l}\text { Non-Standardized } \\
\text { Coef. }\end{array}$} & \multirow{2}{*}{ Std. Coef. } & \multirow{2}{*}{ T test } & \multirow{2}{*}{ Sig. } \\
\cline { 3 - 5 } \multicolumn{2}{|l|}{} & B & Std. Err. & Beta & & \\
\hline \multirow{2}{*}{1} & Constant term & 1.563 & 0.296 & & 4.825 & 0.002 \\
\cline { 2 - 6 } & CSR & 0.317 & 0.137 & 0.442 & 8.503 & 0.014 \\
\hline \multirow{3}{*}{2} & Constant term & 0.842 & 0.726 & & 3.067 & 0.009 \\
\cline { 2 - 6 } & CSR & 0.142 & 0.230 & 0.014 & 2.574 & 0.021 \\
\cline { 2 - 5 } & OI & 0.758 & 0.425 & 0.616 & 8.142 & 0.005 \\
\hline
\end{tabular}

Then we analyze the organization's social responsibility and performance, as shown in Table 9. The equation of corporate social responsibility (CSR), organizational identification $(\mathrm{OI})$ and operating performance $(\mathrm{OP})$ can be shown as:

$$
\begin{aligned}
& O P=\alpha_{1} C S R+\mu_{1} \\
& O P=\alpha_{2} C S R+\beta_{2} O I+\mu_{2}
\end{aligned}
$$

From the table 9, we can see, the regression results show that formula 3 in the constant coefficient for 3.054, significant test results is 0.00 ; organization social responsibility beta $=0.463$, significant test results of 0.003 . The results showed that the organizational social responsibility had a positive correlation to the enterprise operation performance. In formula 4 , it shows that constant coefficient is 2.823 , organization social responsibility significant test results is 0.481 , organizational identification of significant test results is 0.016 ,it means that organizational identification has a mediating effect. 


\section{Table 9. Regression Analysis of CSR and Operating Performance}

\begin{tabular}{|l|l|l|l|l|l|l|}
\hline \multirow{2}{*}{ Model } & \multicolumn{2}{|l|}{ Non-Standardized Coef. } & Std. Coef. & \multirow{2}{*}{ T test } & \multirow{2}{*}{ Sig. } \\
\cline { 2 - 7 } & B & Std. Err. & Beta & & \\
\hline \multirow{2}{*}{1} & Constant term & 3.054 & 0.294 & & 4.716 & 0 \\
\cline { 2 - 7 } & CSR & 1.279 & 0.525 & 0.463 & 6.423 & 0.003 \\
\hline \multirow{3}{*}{2} & Constant term & 2.823 & 0.749 & & 1.382 & 0.035 \\
\cline { 2 - 7 } & CSR & 0.142 & 0.189 & -0.012 & 2.254 & 0.481 \\
\cline { 2 - 6 } & OI & 0.756 & 0.342 & 0.617 & 6.142 & 0.016 \\
\hline
\end{tabular}

\section{Limitations}

Although our study can achieve the goal of the research, and the conclusion has important theoretical and practical significance. But this research still has some limitations in corporate social responsibility, as well as the mechanism of organizational performance and it is still a complex task to test this relationship. The influence factors and the relationship between complex and factors involved in the research model are very limited. We collected data and the selected samples are involved in several industries, and we consider enterprise scale, the nature of the company and industry characteristics as control variables, and then make the conclusion in the complex context in China. Although the conclusion has certain universality, but less targeted, so the research has certain limitations. Through the summary of these limitations and shortcomings, it is helpful for further research in the future.

There are also problems in corporate social responsibility. Although we use conceptual model proposed by Carol, from the perspective of stakeholders to define, but the boundaries of the four dimensions of corporate social responsibility are not completely clear. The boundary of each variable is not very clear, relatively clear is discretionary responsibility, constitute the other three dimensions of corporate social responsibility, the concept boundary is not very clear. Some responsibilities are not clearly divided for pure economic responsibility, legal responsibility and ethical responsibility, there must be in some types of responsibility between them, and in our study, the four dimensions as no intersection of construal to when measured, so we cannot accurately measure each dimension.

At the same time, there are also problem in controlling variables. We use the control variables of enterprise size, enterprise nature and industry properties as controlling variables. The study involved related concepts and construct problem, in management practice and enterprise property. In the nature of the firm and industry characteristics as control variables, of these concepts and constructs in the definition on the lack of a targeted, especially the variables measured. With subjects where the business and industry nature doesn't match with local enterprises, scale items of situational factors and context lack pertinence, the measuring accuracy needs to be improved.

\section{Conclusions}

The research from the perspective of stakeholders, namely universal study of employees from the perspective of corporate social responsibility and organizational performance, the traditional view think corporate social responsibility will inevitably affect the financial performance of the view from the macro can reveal the mechanism of corporate social responsibility and corporate financial performance, our study is from the micro level, the organizational level management perspective to study based on the perspective of stakeholders of corporate social responsibility and organizational performance and through the intermediary role of organizational identification to reveal corporate social responsibility and group weaving mechanism and mechanism of 
performance. Through the study, we can draw the following conclusions: corporate social responsibility is mainly composed of economic responsibility, legal responsibility, ethical responsibility and discretionary responsibility. Empirical results show that corporate social responsibility four parts are on organizational performance has positive and significant influence. All of these indicate that enterprises of staff to fulfill corporate social responsibility are helpful to improve the organizational performance.

\subsection{Enhancement Enterprise's Emphasis on Organizational Social Responsibility}

Tissue obtained profits, not only from organizations operating results, also contains the results from an employee's extra efforts, public consumption and tissue culture environment and political factors interaction. The operation of the organization is inseparable from the surrounding environment, if it wants to continue business must be to establish friendly and harmonious relations with the surrounding environment. At the same time, only take the initiative to fulfill the social responsibility, positive and interaction of the surrounding environment, to meet the expectations of the parties of their own, to get all the support, operations can go far better. Especially when facing difficulties and crisis, social organization perform social responsibility of voice and look forward to more prominent, the more danger pledge, the public more need to organize the courage to assume social responsibility. At the same time, social public and media for the organization is to fulfill social responsibility and organizational social responsibility performance level is more and more attention. This also relates to the organization's reputation and sustainable development.

Organization in the organization to fulfill social responsibility should bear social responsibility connotation and the original intention that organizations are willing to take the initiative to input, and promote the social responsibility of the organization, would make for the sustainable development of the organization and hard and devote resources to do strategic thinking. The results of the motivation will enable the organization to obtain benefits. Importantly, this positive cycle process will enhance the competitiveness, which is organization social responsibility has positive significance; and is not a negative response from all walks of life to the organization bear social responsibility expectation, reluctant to fulfill or perfunctory hypocrisy cope with, organization development and even survival is a fatal threat to. The sustainable development of organization, in addition to the internal organization to achieve the best allocation of resources, but also need to take into account the social responsibility to for the organization to bring the best performance of the business, to achieve sustainable development of the organization's vision. Therefore, the social responsibility of the organization should management attention and concern to all members of the organization, especially, positive view of the public expect to undertake the social responsibility in the organization, organization wide each member contribute their own strength, actively and conscientiously fulfill good organization social responsibility, employees of the organization and the development is very necessary and useful.

\subsection{Pay Attention to the Responsibility of the Stakeholders}

Some organizations for the understanding of organizational social responsibility connotation and thorough enough, one-sided that structure needed only responsible for shareholders, create the maximum economic profit returns to shareholders, and for the organization of other stakeholders in the responsibility to pay attention and perform less or even no phenomenon is not in the minority. As everyone knows, the organization's management and sustained development is not separated from the stakeholders. The competition between the organization and, in the final analysis, is the quality of employees and pay the competition, the organization should people care staff, let employee and organization grow together to urges the organization's core competitiveness. 
Associates efficiently completed duties within the work, even motivate them to complete the extra role behavior; consumer is to organize the source of profits, consumer satisfaction and loyalty in relation to the performance of the organization and survival, so equal treatment of consumers, providing safe and reliable products and services, timely update products to satisfy the consumption is particularly important.

\subsection{Implement Human Resource Management Policy based on Social Responsibility}

Establish the people-oriented organizational culture and actively fulfilling the organizational social responsibility. Positive publicity organization of social responsibility fulfillment and the plan, arouse the members of the organization the organization sense of social responsibility, and actively join the organization to fulfill their social responsibility to act. With the formation of good to fulfill their social responsibility to honor organization atmosphere, and actively develop the stakeholder responsibility policy and implementation plan, let the social from all walks of life experience to undertake social responsibility efforts. Increase for staff training, the organization of staff training and convey organizational social care and staff, social return, pay attention to the value of the common development of employees and organizations view, will make employees aware of my is organized care or attention. Then the positive perception of the staff will greatly enhance the organization's sense of identity. In the existing evaluation system into the assessment of organizational citizenship behavior, so that employees are willing to make benefit colleagues or organizational behavior; secondly, in particular for the staff performance appraisal, more to follow in the use of performance appraisal, perfect performance evaluation and incentive mechanisms enable the firm believe in their own efforts and hard work will get a fair return. At the same time, the organization of the pay system should be closely linked with the performance appraisal system, so that the income and pay proportional to employees. Make sure that the individual's salary is tied to the individual's contribution; make sure employees perceive the fairness of the organization.

\section{References}

[1] D.Alberta.Journal of Financial Economics. vol.111, no. 1, (2014),pp.158-180.

[2] S.Isa.Procedia - Social and Behavioral Sciences. vol.65, no. 3, (2012), pp. 327-337.

[3] M.Kim.International Journal of Hospitality Management.40, (2014), pp.120-129.

[4] B.Lisa and A.Mattila.Journal of Retailing.vol. 91, no. 1, (2015), pp.140-153.

[5] P.Persefoni and I.Evanthia.Procedia Economics and Finance.9, (2014), pp.193-199.

[6] V.Rita.Procedia - Social and Behavioral Sciences. 156, (2014), pp.198-202.

[7] H.Christian and M.Jeremy.Journal of Business Research.vol. 66, no. 10, (2013), pp.1870-1880.

[8] Y.Karaye and Z.Ishak.Procedia - Social and Behavioral Sciences.164, (2014), pp.528-534.

[9] C.Hsueh.International Journal of Production Economics.151, (2014), pp.214-222.

[10] I.Frolova and I.Lapina. Procedia - Social and Behavioral Sciences. vol 156, no. 26,(2014),pp.178-182. 
International Journal of Grid and Distributed Computing

Vol. 9, No. 1 (2016) 